ACTA MYCOLOGICA

Vol. 48 (1): 89-103

2013

DOI: $10.5586 / \mathrm{am} .2013 .011$

\title{
Septoglomus deserticola emended and new combinations in the emended definition of the family Diversisporaceae
}

\author{
JANUSZ BEASZKOWSKI and GERARD CHWAT \\ Department of Plant Protection, West Pomeranian University of Technology \\ Słowackiego 17, PL-71-434 Szczecin, janusz.blaszkowski@zut.edu.pl
}

Błaszkowski J., Chwat G.: Septoglomus deserticola emended and new combinations in the emended definition of the family Diversisporaceae. Acta Mycol. 48 (1): 89-103, 2013.

An updated morphology of spores of Septoglomus deserticola, an arbuscular mycorrhizal fungus of the phylum Glomeromycota, is presented based on the original description of the species, only one other its definition recently published and spores produced in pot cultures inoculated with the rhizosphere soil and root fragments of an unrecognized grass colonizing maritime sand dunes of the Hicacos Peninsula, Cuba. Phylogenetic analyses of sequences of the large subunit (LSU) nrDNA region of the Cuban fungus confirmed its affinity with $S$. deserticola deposited in the International Bank for the Glomeromycota (BEG) and indicated that its closest relatives are $S$. fuscum and $S$. xanthium. Phylogenetic analyses of sequences of the small subunit (SSU) nrDNA confirmed the Cuban fungus x $S$. fuscum x $S$. xanthium relationship revealed in analyses of the LSU sequences and thereby suggested the Cuban Septoglomus is $S$. deserticola. However, it was impossible to prove directly the identity of the Cuban fungus and $S$. deserticola from BEG based on SSU sequences due to the lack of $S$. deserticola SSU sequences in public databases. In addition, phylogenetic analyses of LSU and SSU sequences confirmed the uniqueness of the recently erected genus Corymbiglomus with the type species C. corymbiforme (formerly Glomus corymbiforme) in the family Diversisporaceae and proved that its LSU sequences group in a clade with LSU sequences of G. globiferum and G. tortuosum. Consequently, the two latter species were transferred to Corymbiglomus and named C. globiferum comb. nov. and C. tortuosum comb. nov., and the definitions of the family Diversisporaceae and the genus Diversispora were emended.

Key words: arbuscular mycorrhizal fungi, Glomeromycota, taxonomy 


\section{INTRODUCTION}

Arbuscular mycorrhizal fungi (AMF) of the phylum Glomeromycota are associated with ca. 70-90\% of land plants (Smith, Read 2008; Brundrett 2009), including those growing in extremely poor maritime sand dunes (Koske 1987; Dalpé 1989; Tadych, Błaszkowski 2000). It is recognized that maritime sand dunes especially favor the development of AMF because of the low content of nutrients and organic matter (Błaszkowski et al. 2009; Błaszkowski 2012). The fungi frequently increase the supply of plants with nutrients and decrease their sensitivity to different abio- and biotic stresses (Schönbeck 1978; Dehn, Schüepp 1989; Griffioen, Ernst 1989; Smith, Read 2008). Although even low colonization of plant roots by AMG can alleviate such stresses (Pongrac et al. 2007), the effect of influence of AMF may differ, because different species or even strains of a given species of AMF may variously affect plants (Abbott, Robson 1981; Kaldorf et al. 1999; Maherali, Klironomos 2007; Sýkorová et al. 2011). Hence numerous unsuccessful attempts of application of AMF probably partly resulted from erroneous species identification and the difficult nature of AM fungal taxonomy (Schüßler et al. 2011; Krüger et al. 2012).

At present the phylum Glomeromycota comprises three classes, five orders, 15 families, 34 genera and ca. 250 species (Oehl et al. 2011a-e; Schüßler, Walker 2010; Błaszkowski 2012). However, results of molecular phylogenetic analyses of sequences of nrDNA extracted from plant roots suggest that less than $5 \%$ of the existing species in the world are known to date and that most undescribed species form glomoid spores (Krüger et al. 2009), i.e. spores similar in mode of formation, spore wall structure and in characters of their subtending hypha to those of Glomus macrocarpum Tul. \& C. Tul., the type species of the genus Glomus Tul. \& C. Tul. (Schüßler, Walker 2010). Of the described species, ca. $62 \%$ produce typical glomoid spores. Glomoid spores form Pacispora spp. as well, but they have two spore walls (vs. one in typical glomoid spores), an outer wall, forming the spore surface, and an inner wall, called a germinal wall (Błaszkowski 2012).

Apart from Glomus spp., glomoid spores form fungi of 15 other genera, among which the recently erected genus Septoglomus Sieverd., G.A. Silva \& Oehl is, whose type species is $S$. constrictum (Trappe) Sieverd., G.A. Silva \& Oehl. (Oehl et al. 2011c). Currently the genus Septoglomus comprises seven species whose spores are dark-coloured and have a 2- to 3-layered spore wall with the innermost layer being laminate (Oehl et al. 2011c; Błaszkowski et al. 2012). None of the layers stains in Melzer's reagent. The spore subtending hyphae of the species usually is cylindrical or constricted, and its pore is closed by a septum.

We established single-species cultures from dark-coloured glomoid spores of the Glomeromycota isolated from a trap culture inoculated with the rhizosphere soil and root fragments of an unrecognized grass colonizing maritime sand dunes of the Hicacos Peninsula, Cuba. Morphological studies of these spores suggested we found an AMF closely related to $S$. deserticola (Trappe, Bloss \& J.A. Menge) G.A. Silva, Oehl \& Sieverd. Apart from the original description of $S$. deserticola as G. deserticola (Trappe et al. 1984), in the literature there is only one other report of morphology of the species prepared from spores obtained from the International Bank for the Glomeromycota (BEG; Błaszkowski 2012). Our doubt of the identity of the two 
fungi resulted from differences in colour of their spores; the spores from Cuba were lighter. However, subsequent phylogenetic analyses of sequences of the large subunit (LSU, partial) spore nrDNA region unambiguously placed the Cuban fungus among available LSU sequences of $S$. deserticola. We also obtained sequences of the small subunit (SSU) nrDNA of the fungus from Cuba, but we could not confirm its identity to $S$. deserticola due to the lack of SSU sequences of $S$. deserticola in available databases. However, our phylogenic analyses indicated that the position of the Cuban fungus in a tree with SSU sequences relative to other Septoglomus spp. was identical to that in the LSU tree, suggesting the Cuban Septoglomus is S. deserticola. Thus our SSU sequences significantly widened the range of molecular data on $S$. deserticola.

Phylogenetic analyses of LSU sequences of G. corymbiforme Błaszk. recently lead to the erection of a new genus, Corymbiglomus Błaszk. et Chwat, with the type species, C. corymbiglomus (Błaszk.) Błaszk. et Chwat (Błaszkowski 2012). Subsequent analyses of LSU and SSU sequences of this species confirmed the uniqueness of Corymbiglomus and its phylogenetic relationship to Diversispora C. Walker et A. Schüssler, emend. G.A. Silva, Oehl et Schüssler and indicated that other species grouping in a clade with LSU sequences of $C$. corymbiforme are $G$. globiferum Koske et C. Walker and G. tortuosum N.C. Schenck et G.S. Sm. Thus results of the analyses and morphological similarity of spores of the tree species proved that G. globiferum and $G$. tortuosum should became members of the genus Corymbiglomus.

The aims of this paper are to update the knowledge on morphology and phylogeny of $S$. deserticola, emend the definitions of the family Diversisporaceae and the genus Diversispora and to transfer G. globiferum and G. tortuosum to the genus Corymbiglomus.

\section{MATERIALS AND METHODS}

Establishment and growth of trap and single-species cultures, extraction of spores, and staining of mycorrhizae. Spores examined in this study were derived from both pot trap and single-species cultures. Trap cultures were established to obtain living spores and to initiate sporulation of species that may not have sporulated in the field collections (Stutz, Morton 1996). The method used to establish trap cultures, their growing conditions and the methods of spore extraction and staining of mycorrhizae were as those described previously (Błaszkowski et al. 2012b). The growing substrate of trap cultures was the field-collected rhizosphere soil and roots of the plant species sampled mixed with autoclaved coarse grained sand.

Single-species cultures were also established and grown as given in Błaszkowski et al. (2012b). Briefly, the cultures of $S$. deserticola were successfully established from small clusters of spores (5-15) attached by a common mycelium. The growing substrate of the cultures was autoclaved commercially available coarse-grained sand (grains 1.0-10.0 mm diam - 80.50\%; grains 0.1-1.0 mm diam - 17.28\%; grains $<0.1 \mathrm{~mm}$ diam $-2.22 \%)$ mixed $(5: 1, \mathrm{v} / \mathrm{v})$ with clinopthilolite (Zeocem, Bystré, Slovakia) of grains $2.5-5 \mathrm{~mm}$. Clinopthilolite is a crystaline hydrated alumosilicate of alkali metals and alkaline earth metals having, e.g. high ion exchange 
capability and selectivity, as well as reversible hydration and dehydration. The sand-clinopthilolite mixture had a $\mathrm{pH}$ of 7.3. The cultures were kept in transparent plastic bags, $15 \mathrm{~cm}$ wide and $22 \mathrm{~cm}$ high as suggested by Walker and Vestberg (1994). The cultures were watered with tap water once or twice a week, harvested after five months when spores were extracted for study. To reveal mycorrhizal root structures, root fragments located ca. $1-5 \mathrm{~cm}$ below the upper level of the growing medium were cut off with a scalpel. Plantago lanceolata L. was used as host plant in both trap and single-species cultures.

Microscopy. Morphological properties of spores and their wall structure were determined after examination of at least 100 spores mounted in water, lactic acid, polyvinyl alcohol/lactic acid/glycerol (PVLG; Omar et al. 1979) and a mixture of PVLG and Melzer's reagent $(1: 1, \mathrm{v} / \mathrm{v})$. Spores at all developmental stages were crushed to varying degrees by applying pressure to the cover slip and then stored at $65^{\circ} \mathrm{C}$ for $24 \mathrm{~h}$ to clear their contents from oil droplets and examined under an Olympus BX 50 compound microscope equipped with Nomarski differential interference contrast optics. Microphotographs were recorded on a Sony 3CCD color video camera coupled to the microscope.

Terminology of spore structure is that suggested by Stürmer and Morton (1997) and Walker (1983). Spore color was examined under a dissecting microscope on fresh specimens immersed in water. Color names are from Kornerup and Wanscher (1983). Nomenclature of plants is after Mirek et al. (http://info.botany.pl/czek/check. $\mathrm{htm}$ ), and that of fungi and the authors of fungal names are those presented at the Index Fungorum website http://www.indexfungorum.org/AuthorsOfFungalNames. htm. Voucher specimens were mounted in PVLG and a mixture of PVLG and Melzer's reagent $(1: 1, \mathrm{v} / \mathrm{v})$ on slides and deposited in the Department of Plant Protection (DPP), West Pomeranian University of Technology, Szczecin, Poland.

DNA extraction, Polymerase Chain Reaction and DNA sequencing. Crude DNA was isolated from small spore clusters crushed with a needle in ultra clean water on sterile microscope slides under a dissecting microscope. Amplification, cloning and sequencing were carried out as described in Błaszkowski et al. (2012a). The partial LSU was amplified using the nested PCR with the primer pairs ITS3-28G2 (da Silva et al. 2006; White et al. 1990) and LR1-28G2 (da Silva et al. 2006; van Tuinen et al. 1998), and the partial nrSSU segment was amplified with the primers AML1 and AML2 (Lee et al. 2008). PCR was performed with DreamTag Green PCR Master Mix (2X) (Thermo Scientific, Germany). The PCR conditions for LSU were as those described by Oehl et al. (2011d), and those for SSU were: initial 5 min denaturation at $94^{\circ} \mathrm{C}$ followed by 30 cycles of $45 \mathrm{~s}$ denaturation at $94^{\circ} \mathrm{C}, 45 \mathrm{~s}$ annealing at $58^{\circ} \mathrm{C}$, $45 \mathrm{~s}$ elongation at $72^{\circ} \mathrm{C}$ and final $5 \mathrm{~min}$ elongation at $72^{\circ} \mathrm{C}$. The subsequent work with amplicons was carried out as described in Błaszkowski et al. (2012b).

Sequence alignment and phylogenetic analyses. Phylogenetic analyses were performed separately with LSU and SSU sequences. To determine the generic affiliation of the Cuban fungus we performed pilot phylogenetic analyses of all its LSU and SSU sequences we obtained with those representing all recognized genera of the Glomeromycota with glomoid spores available in GenBank. The final data sets comprised all our sequences of the putative $S$. deserticola, all published sequences of $S$. deserticola (only LSU sequences), one sequence each of all other described Septoglomus spp. (LSU and SSU), except the sequence AF145741 (da Silva et al. 
2006), and sequences of other species with glomoid spores mainly deriving from the former Glomus group A (Schwarzott et al. 2001). The sequence AF145741 probably represents Funneliformis coronatus (Giovann.) C. Walker \& A. Schüßler (da Silva, pers. comm.) whose small-spored isolates closely resemble $S$. constrictum spores (Błaszkowski, pers. observ.). The LSU and SSU sequences were aligned with Clustal W (Thompson et al. 1994) with default parameters. Maximum likelihood (ML) and Bayesian (BI) analyses were performed with PHYML (Guindon and Gascuel 2003) and MrBayes 3.1 (Huelsenbeck, Ronquist 2001; Ronquist, Huelsenbeck 2003), respectively. Before the analyses the best-fit substitution models for the alignments were estimated by the Akaike information criterion (AIC) using Topali v. 2.5 (Milne et al. 2004). Pacispora scintillans (S.L. Rose \& Trappe) Sieverd. \& Oehl ex C. Walker, Vestberg \& A. Schüßler was outgroup in all analyses. In the ML analyses of LSU and SSU sequences the model employed was $\operatorname{TrN}+\mathrm{G}$, and in the BI analyses of both types of sequences we applied GTR $+\mathrm{G}$ and $\mathrm{HKY}+\mathrm{G}$, respectively. In the ML analysis the transition/transversion ratio for DNA models and the gamma distribution parameter were estimated. Six substitution rate categories were set. Topology and branch lengths and rate parameters were optimized. Support of branches in the ML analysis was estimated in a bootstrap analysis with 1000 replicates. In the BI analyses the Markov chain was run for 5000000 generations, sampling in every 500 steps, and with a burn-in at 3000. The details of the analyses are available on request. Phylogenetic trees were visualized and edited in MEGA5 (Tamura et al. 2011).

\section{RESULTS}

Molecular analyses. Maximum likelihood and BI analyses of LSU sequences generated trees of identical topologies. All sequences of the Cuban fungus clustered in a monophyletic group with published sequences of $S$. deserticola, whose a sister clade comprised all the other known Septoglomus spp. except for S. titans (Fig. 1). The $S$. titans sequence formed a separate branch at the base of the Septoglomus clade. Both the clade with S. deserticola sequences and the other monophyletic groups of the Septoglomus clade were well supported [bootstrap supports (BS) of all clades of $>90 \%$, except for one clade of $69 \%$; posterior probabilities (PP) of all clades of 1 , except for one clade of 0.89]. The closest molecular relatives of the Cuban $S$. deserticola were $S$. fuscum Błaszk. et al. and S. xanthium Błaszk. et al.

The topologies of trees obtained following ML and BI analyses of SSU sequences also were identical. The SSU sequences of the Cuban fungus grouped in a clade sister to that with sequences of $S$. africanum, $S$. constrictum, S. fuscum and S. xanthium (Fig. 2). The recently described S. furcatum (Blaszkowski et al. 2012) represented a separate linage positioned at the base of the Septoglomus clade. The clade with the Cuban $S$. deserticola sequences received very strong supports $(\mathrm{BS}=100 \%, \mathrm{PP}=1)$, and the supports of the other groups of the Septoglomus clade were moderate to high. Similarly as in the LSU tree, the Cuban $S$. deserticola was most closely related to $S$. fuscum and S. xanthium (Fig. 2). Unfortunately, we could not determine the similarity of the SSU sequences of the Cuban $S$. deserticola with other SSU sequences of this species because of their unavailability in public databases. 


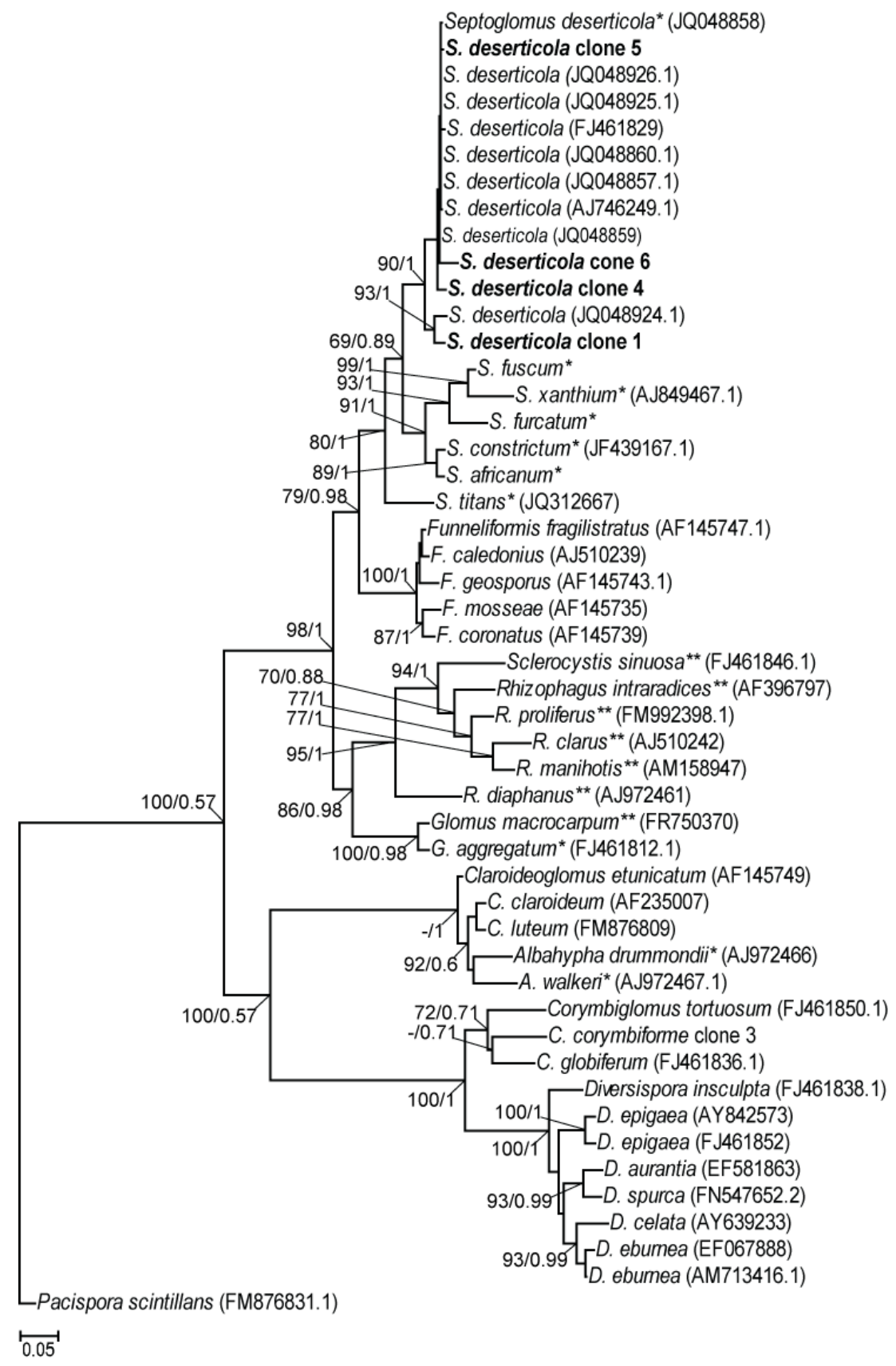

Fig. 1. Maximum likelihood (ML) tree inferred from LSU nrDNA sequences with Pacispora scintillans as outgroup. GenBank accession numbers of the sequences are in parentheses. ML bootstrap values $\geq 50 \%$ and the Bayesian posterior probabilities $\geq 0.50$ are shown near the branches, respectively. Sequences of the Cuban $S$. deserticola are in boldface. * $=$ sensu Oehl et al. 2011a, ${ }^{* *}=$ sensu Schüßler and Walker 2010. Bar indicates 0.05 expected change per site per branch. 


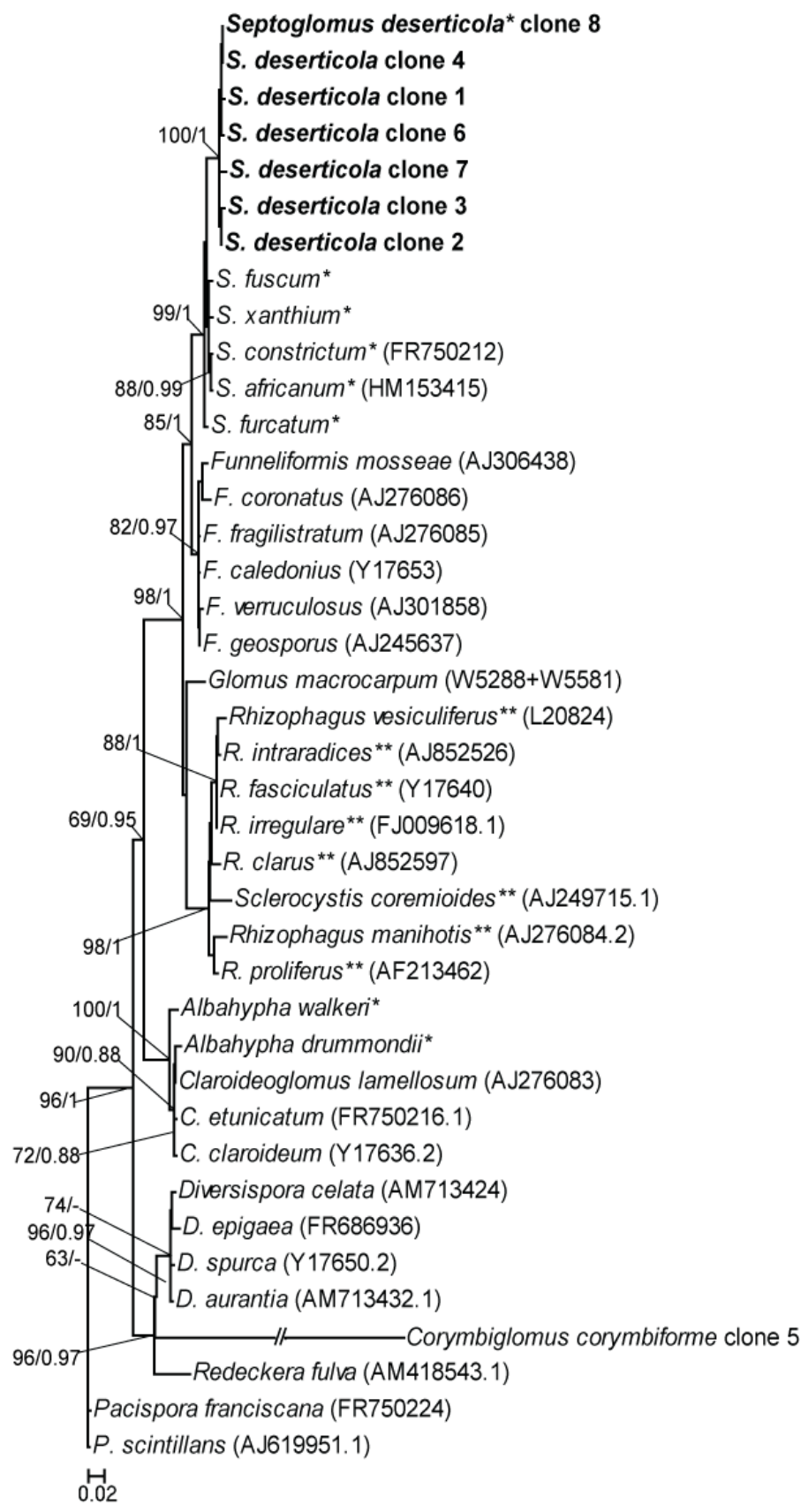

Fig. 2. Maximum likelihood (ML) tree inferred from SSU nrDNA sequences with Pacispora scintillans as outgroup. GenBank accession numbers of the sequences are in parentheses. ML bootstrap values $\geq 50 \%$ and the Bayesian posterior probabilities $\geq 0.50$ are shown near the branches, respectively. Sequences of the Cuban $S$. deserticola are in boldface. Branch with the Corymbiglomus corymbiforme sequence is shortened by $50 \%{ }^{*}=$ sensu Oehl et al. 2011a, ** = sensu Schüßler and Walker 2010. Bar indicates 0.02 expected change per site per branch. 


\section{TAXONOMY}

Septoglomus deserticola (Trappe, Bloss et J.A. Menge) G.A. Silva, Oehl et Sieverd. Mycotaxon 116: 106. 2011. Figs 3-10 इGlomus deserticola Trappe, Bloss \& J.A. Menge. Mycotaxon 20: 123. 1984.

Spores arise in soil singly or in loose clusters lacking a peridium (Figs 3, 7). Spores deep yellow (4A8) to light brown (6D8), globose to subglobose, (19-)82(-135) $\mu \mathrm{m}$ diam., sometimes ovoid to pear-shaped, 59-71 $\times 72-155 \mu \mathrm{m}$, with one subtending hypha (Figs 3-9). Spore wall composed of two layers (Figs 4, 5, 7-9). Layer 1, forming the spore surface, evanescent, hyaline, $(0.5-) 1.3(-2.3) \mu \mathrm{m}$ thick, frequently completely sloughed in mature spores (Figs 4, 5, 7-9). Layer 2 laminate, smooth, deep yellow (4A8) to light brown (6D8), (1.8-)2.5(-3.8) $\mu \mathrm{m}$ thick, frequently thickened at the spore base to form a collar (Figs 4, 5, 7-9). Layers 1 and 2 do not stain in Melzer's reagent. Subtending hypha deep yellow (4A8) to light brown (6D8), straight or curved, flared, funnel-shaped, rarely constricted at the spore base, (6.3-)8.1-13.3(16.8) $\mu \mathrm{m}$ wide at the spore base (Figs 5,7). Wall of subtending hypha deep yellow (4A8) to light brown (6D8), composed of two layers continuous with spore wall layers 1 and 2 (Figs 5, 7). Layer $1(0.8-) 1.0(-1.3) \mu \mathrm{m}$ thick, layer $2(2.5-) 3.2(-3.8) \mu \mathrm{m}$ thick; the outer and inner surfaces of layer 2 frequently with side thickenings (Figs 5 , 7). Pore open, (0.8-)3.1-6.5(-10.8) $\mu \mathrm{m}$ wide at the spore base (Figs 5, 7). Hyphae of clusters deep yellow (4A8) to light brown (6D8), straight or branched, (8.0-)11.3(16.8) $\mu \mathrm{m}$ wide, with a 2-layered wall: a hyaline, evanescent, $(0.8-) 1.5(-2.5) \mu \mathrm{m}$ thick, when intact, outer layer and a deep yellow (4A8) to light brown (6D8), permanent, $(2.0-) 2.6(-2.8) \mu \mathrm{m}$ thick inner layer (Figs 3, 5, 6, 9, 10). Germination unknown.

Mycorrhizae. In the field, associated with roots of an unrecognized grass. In addition, lived in symbiosis with Parthenium argentatum A. Gray, P. incanum Kunth, Simmondsia chinensis (Link) C.K. Schneid. (Trappe et al. 1984) and Uniola paniculata L. (Sylvia 1986; Sylvia \& Will 1988).

The characters of mycorrhizae from single-species culture of $S$. deserticola remain unknown.

Etymology. Latin, deserticola (desert dweller), referring to the sandy desert soils in which the fungus was originally found (Trappe et al. 1984).

SPECIMENS EXAMINED. Poland. Szczecin, Btaszkowski J., 3144-3146 (DPP), prepared from spores obtained from BEG. Szczecin, under pot-cultured P. lanceolata, 18 Dec. 2012, Btaszkowski J., 3353-3357 (DPP), originally coming from the Hicacos Peninsula, Cuba.

Distribution and habitat. Found associated with roots of an unrecognized grass colonizing maritime sand dunes of the Hicacos Peninsula, Cuba.

Originally described from spores isolated from sandy desert soils of Arizona, southern California and Texas (U.S.A.; Trappe et al. 1984). Also recorded in maritime dunes of Florida (Sylvia 1986; Sylvia, Will 1988), as well as in other habitats of the U.S.A. (Paulitz, Menge 1986; Bloss, Walker 1987; Augé 1989), Spain (Arines, Vilarino 1991) and India (Ragupathy, Mahadevan 1993). Probably many times mistakenly identified as Rhizophagus fasciculatus (Thaxt.) C. Walker $\&$ A. Schüssler (formerly G. fasciculatum (Thaxter) Gerd. et Trappe (Trappe et al. 1984; Walker, Koske 1987), one of the most frequently reported AMF from 


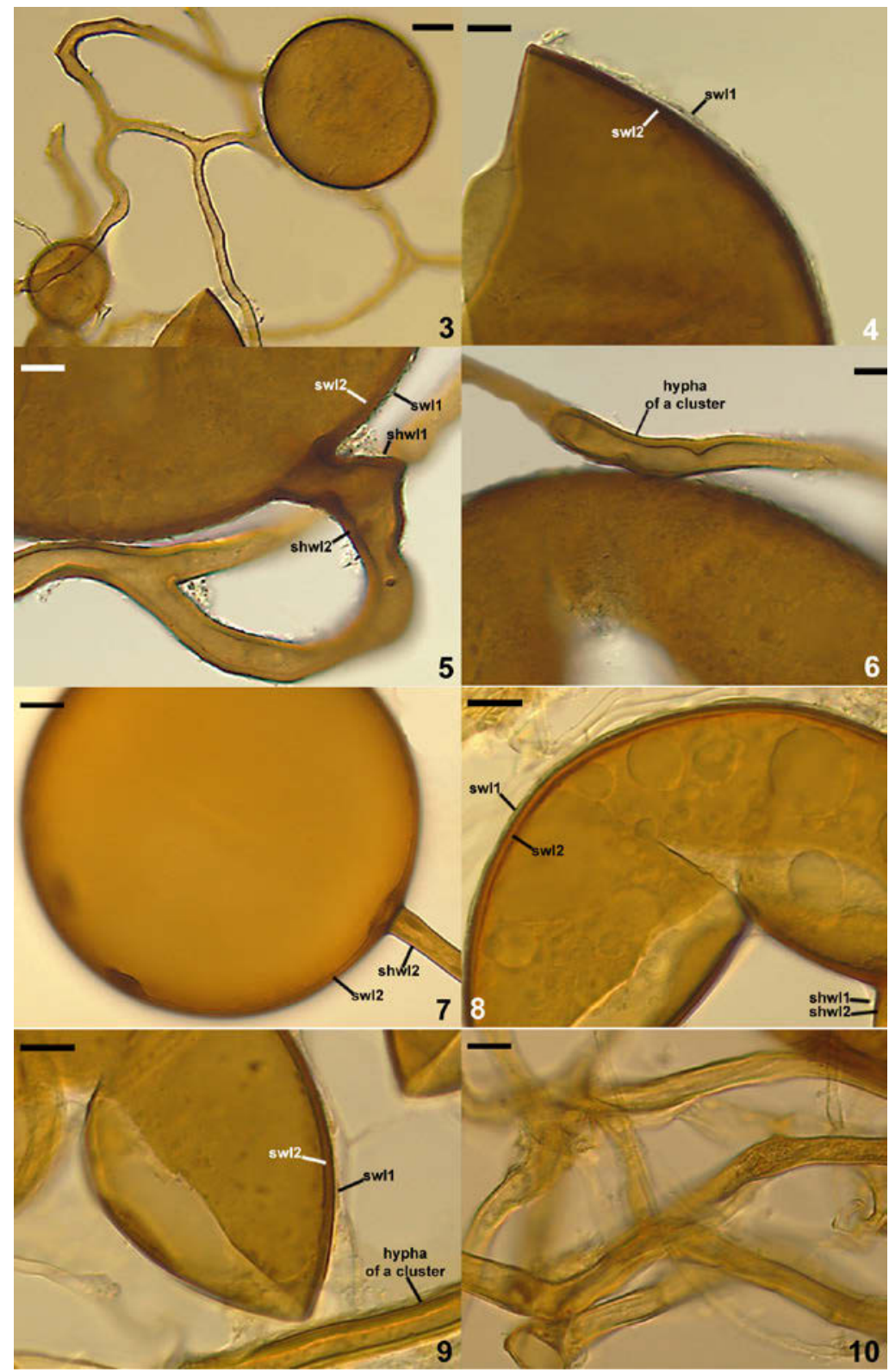

Figs 3-6. Septoglomus deserticola from BEG. 3. Intact spores in a loose cluster. 4. Spore wall layers (swl) 1 and 2. 5. Spore wall layers (swl) 1 and 2 and subtending hyphal wall layers (shwl) 1 and 2. 6. Thick-walled hypha of a cluster and a spore. Figs. 7-10. Septoglomus deserticola from Cuba. 7. Spore wall layer (swl) 2 and subtending hyphal wall layer (shwl) 2 of intact spore; swl1 and shwl1 are completely sloughed. 8. Spore wall layers (swl) 1 and 2 and subtending hyphal wall layers (shwl) 1 and 2; shwl1 is highly deteriorated. 9. Spore wall layers (swl) 1 and 2 and a 2-layered hypha of a cluster. 10. Loose hyphae of a cluster. Figs. 3, 5-7, 10. Spores in PVLG. Figs. 4, 8, 9. Spores in PVLG+Melzer's reagent. Figs 3-10, differential interference microscopy. Bars: Fig. $3=20 \mu \mathrm{m}$, Figs. $4-10=10 \mu \mathrm{m}$. 
soil surveys and most often cited as used in studies of plant growth responses (Walker 1985). The fungus reported many times under the epithet $S$. deserticola (Błaszkowski 2012) from different regions of Poland probably is its close undescribed relative. Spores of the fungus are lighter [pale yellow (3A3) to orange (6A6)] and their spore wall layer 1 stains in Melzer's reagent (Błaszkowski 1990; vs. no reaction in $S$. deserticola).

Notes. Morphologically, $S$. deserticola is most distinguished by its dark-coloured and relatively small spores usually formed in loose clusters (Figs 3-9).

Phylogenetically and morphologically $S$. deserticola is closest to S. fuscum (Figs $1,2)$, a species recently described from a material coming from maritime sand dunes located near Strand, ca. $50 \mathrm{~km}$ southeast of Cape Town, South Africa (Błaszkowski et al. 2012). Both species produce dark-coloured, relatively small spores, usually in loose clusters and have a 2-layered spore wall (Trappe et al. 1984; Błaszkowski 2012; Błaszkowski et al. 2012). However, the mean diameter of globose $S$. deserticola spores is almost 2-fold higher, their spore wall layer 1 is short-lived and usually completely sloughed in mature spores (Fig. 7; vs. semi-persistent, rarely partly deteriorated in mature and older spores in S. fuscum) and hyaline (Figs 4, 5, 8, 9); vs. coloured, rarely hyaline), and spore wall layer 2 is much thinner. In addition, the spore subtending hypha of $S$. deserticola is much wider and has much thicker walls and a wider pore.

Septoglomus xanthium, another species close in phylogeny to $S$. deserticola (Figs 1,2), also forms spores almost indistinguishable from those of the latter fungus when they are intact and seen under a dissecting microscope. The two species mainly separate the number of spore wall layers (three vs. two in S. deserticola; Figs. 4, 5, 8, 9) and the phenotypic features of spore wall layer 1 , forming the spore surface (semi-permanent and coloured in mature spores vs. hyaline and usually completely sloughed at maturity; Figs. 4, 5, 7-0; Trappe et al. 1984; Błaszkowski et al. 2004; Błaszkowski 2012). In addition, $S$. xanthium spores are clearly smaller $[(23-) 50-70) \mu \mathrm{m}$ diam when globose vs. (19-)82(135) $\mu \mathrm{m}$ diam when globose], have a much thinner structural laminate spore wall layer and a narrower subtending hypha with thinner walls and a narrower pore.

Of other known species of the Glomeromycota, S. deserticola may be confused with small-spored isolates of Funneliformis coronatus (Giovann.) C. Walker \& A. Schüssler, $S$. constrictum and $S$. furcatum Błaszk., Chwat \& Kovács, Ryszka due to their similarly coloured spores (Błaszkowski 2012; Błaszkowski et al. 2012). However, spores of the three latter species usually are much larger and arise only singly (vs. singly and in clusters in S. deserticola; Figs 3-9). Other differences between the four species reside in their spore wall structure, phenotypic and histochemical characters of spore wall layers, spore subtending hyphal features and, most importantly, in their phylogenies (Figs 1,2).

\section{EMENDATIONS AND NEW COMBINATIONS}

\section{Diversisporaceae C. Walker \& A. Schüßler, emend. Błaszk. et Chwat}

Forming spores blastically at the top of a sporogenous hypha (Glomus-like spores), laterally on the neck of a sporiferous saccule (Acaulospora-like spores) or inside the neck of a sporiferous saccule (Entrophospora-like spores). Acaulospora-like 
spores and Entrophospora-like spores as otosporoid and tricisporoid spores, respectively, sensu Oehl et al. (2011e). Glomus-like spores without a hyphal mantle (diversisporoid spores sensu Oehl et al. 2011e) or covered individually with a hyphal mantle consisting of non-branched or branched hyphae. Mantled spores occurring singly or in clusters with two to three spores grouped by interwoven hyphae of their hyphal mantle or in clusters with two to $<20$ spores formed by spores arisen at the top of sporogenous hyphae dichotomously branched from a parent hypha continuous with an extraradical mycorrhizal hypha. Spores pigmented, with a 1-3-layered spore wall. Subtending hypha straight or recurved, cylindrical to funnel-shaped or constricted. Subtending hyphal wall continuous with and coloured similarly to the spore wall. Pore open or occluded by a septum continuous with the innermost laminae of the structural spore wall, by thickening of the structural spore wall or by spore wall layer 3.

Type genus: Diversispora C. Walker et A. Schüssler emend. G.A. Silva, Oehl et Sieverd. Mycotaxon 116: 108. 2011c.

Other genera: Corymbiglomus Błaszk. et Chwat. Glomeromycota 272. 2012.

Otospora Oehl, Palenz. et N. Ferrol. Mycologia 100: 297. 2008

Redeckera C. Walker et A. Schüssler, emend. Oehl, G.A. Silva \&Sieverd. Mycotaxon 116: 110. 2011c.

Tricispora Oehl, Sieverd., G.A. Silva et Palenz. Mycotaxon 117: 310. 2011e.

Corymbiglomus Błaszk. et Chwat, emend.

Forming Glomus-like spores individually covered with a hyphal mantle consisting of non-branched or branched hyphae with or without terminal vesiculate swellings. Spores occurring singly or in clusters. Clusters with two to three spores grouped by interwoven hyphae of their hyphal mantle or with two to $<20$ spores arisen at the top of sporogenous hyphae dichotomously branched from a parent hypha continuous with an extraradical mycorrhizal hypha. Spores pigmented, with a 1-3-layered spore wall. Subtending hypha straight or recurved, cylindrical to funnel-shaped or constricted. Subtending hyphal wall continuous with and coloured similarly to the spore wall. Pore open or occluded by a septum continuous with the innermost laminae of the structural spore wall, by thickening of the structural spore wall or by spore wall layer 3.

Type species: Corymbiglomus corymbiforme (Błaszk.) Błaszk. et Chwat. Glomeromycota 274. 2012.

Other species: Corymbiglomus globiferum (Koske et Walker) Błaszk et Chwat, comb. nov.

三Glomus globiferum Koske et Walker. Mycotaxon 26: 133. 1986.

Corymbiglomus tortuosum (N.C. Schenck et G.S. Sm.) Błaszk. et Chwat, comb. nov. =Glomus tortuosum N.C. Schenck et G.S. Sm. Mycologia 74: 83. 1982.

Notes. The genus Corymbiglomus was originally erected based on phylogenetic analyses of LSU sequences of G. corymbiforme Błaszk. (Błaszkowski 2012). Results of phylogenetic analyses of LSU and SSU sequences presented here confirmed those 
of earlier studies (Błaszkowski 2012) and clearly revealed that species grouping with C. corymbiforme in a clade with LSU sequences also are G. globiferum and G. tortuosum (Figs 1,2). Similarly as in the phylogenetic analyses of LSU sequences, those of SSU sequences placed $C$. corymbiforme in a position sister to the clade with known Diversispora spp. Unfortunately, we could not determine the C. corymbiglomus $\mathrm{x}$ C. globiferum x C. tortuosum relationship found in the analyses of LSU sequences, because there are no SSU sequences of the latter two species in available databases. Morphologically, the species link that their spores are covered with a hyphal mantle and they usually occur in clusters.

Acknowledgements This study was supported in part by the National Centre of Science, grants no. N N304 061739 and 2012/05/B/NZ8/00498. Ananonymous reviewers are kindly acknowlegment for their valuable suggestions.

\section{REFERENCES}

Abbott L. K., Robson A. D. 1981. Infectivity and effectiveness of five endomycorrhizal fungi: competition with indigenous fungi in field soils. Aust. J. Agric. Res. 32: 621-630.

Arines J., Vilarino A. 1991. Growth, micronutrient content and vesicular-arbuscular fungi infection of herbaceous plants on lignite mine spoils: a greenhouse pot experiment. Plant and Soil 135: 269-273.

Augé R.M. 1989. Do VA mycorrhizae enhance transpiration by affecting host phosphorous content? J. Plant nutrition 12: 743-753.

Bloss H.E., Walker C. 1987. Some endogonaceous mycorrhizal fungi of the Santa Catalina Mountains in Arizona. Mycologia 79: 649-654.

Błaszkowski J. 1990. Polish Endogonaceae IV. Gigaspora gigantea, Glomus deserticola, and Glomus globiferum. Acta Mycol. 26: 3-16.

Błaszkowski J. 2012. Glomeromycota. W. Szafer Institute of Botany, Polish Academy of Sciences, Kraków.

Błaszkowski J., Blanke V., Renker C., Buscot F. 2004. Glomus aurantium and G. xanthium, new species in Glomeromycota. Mycotaxon 90: 447-467.

Błaszkowski J., Chwat G., Kovács G. M., Gáspár B.K., Ryszka P., Orłowska E., Pagano M.C., Araújo F.S., Wubet T., Buscot F. 2012a. Septoglomus fuscum and S. furcatum, two new species of arbuscular mycorrhizal fungi (Glomeromycota). Mycologia 12-127. DOI:10.3852/12-127

Błaszkowski J., Kovács G.M., Balázs T. 2009. Glomus perpusillum, a new arbuscular mycorrhizal fungus. Mycologia 101(2): 245-253.

Błaszkowski J., Kovács G.M., Gáspár B.K., Balázs T.K., Buscot F., Ryszka P. 2012b. The arbuscular mycorrhizal Paraglomus majewskii sp. nov. represents a new distinct basal lineage in Paraglomeraceae (Glomeromycota). Mycologia 104: 148-156. DOI: 10.3852/10-430

Brundrett M.C. 2009. Mycorrhizal associations and other means of nutrition of vascular plants: understanding the global diversity of host plants by resolving conflicting information and developing reliable means of diagnosis. Plant Soil 320: 37-77.

Dalpé Y. 1989. Inventaire et repartition de la flore endomycorhizienne de dunes et de rivages maritimes du Quebec, du Nouveau-Brunswick et de la Nouvelle-Ecosse. Naturaliste can (Rev Ecol Syst) 116: 219-236.

Dehn B., Schüepp H. 1989. Influence of VA mycorrhizae on the uptake and distribution of heavy metals in plants. Agric. Ecosys. Environment 29: 79-83.

Griffioen W.A., Ernst W.H.O. 1989. The role of VA mycorrhiza in the heavy metal tolerance of Agrostis capillaris L. Agric. Ecosys. Environment 29: 173-177.

Guindon S., Gascuel O. 2003. A simple, fast, and accurate algorithm to estimate large phylogenies by maximum likelihood. Syst. Biol 52: 696-704.

Huelsenbeck J.P., Ronquist F. 2001. MRBAYES: Bayesian inference of phylogeny. Bioinformatics 17: 754-755. 
Kaldorf M.O., Kuhn A.J., Schröder W.H., Hildebrandt U., Bothe H. 1999. Selective element deposits in maize colonized by a heavy metal tolerance conferring arbuscular mycorrhizal fungus. J. Plant Physiol. 154: 718-728.

Kornerup A., Wanscher J.H. 1983. Methuen handbook of colour. 3rd ed. London: Eyre Methuen. 252 pp.

Koske R.E. 1987. Distribution of VA mycorrhizal fungi along a latitudinal temperature gradient. Mycologia 79: 55-68.

Koske R.E., Walker C. 1986. Glomus globiferum: a new species of Endogonaceae with a hyphal peridium. Mycotaxon 26: 133-142.

Krüger M., Stockinger H., Krüger C., Schüßler A. 2009. DNA-based species level detection of Glomeromycota: one PCR primer set for all arbuscular mycorrhizal fungi. New Phytol. 183: 212-223.

Krüger M., Krüger C., Walker C., Stockinger H., Schüßler A. 2012. Phylogenetic reference data for systematics and phylotaxonomy of arbuscular mycorrhizal fungi from phylum to species level. New Phytol. 193: 970-984. DOI: 10.1111/j.1469-8137.2011.03962.x

Lee J., Lee S., Young J.P. 2008. Improved PCR primers for the detection and identification of arbuscular mycorrhizal fungi. FEMS Microbiol. Ecol. 65: 339-349.

Maherali H., Klironomos J.M. 2007. Influence of phylogeny on fungal community assembly and ecosystem functioning. Science 316: 1746-1748.

Milne I., Wright F., Rowe G., Marshal D.F., Husmeier McGuire G. 2004. TOPALi: Sofware for authomatic identification of recombinant sequences within DNA Multiple Alignments. Bioinformatics 20: 1806-1807. http://dx.doi.org/10.1093/bioinformatics/bth155

Oehl F., Sieverding E., Palenzuela J. Ineichen K., da Silva G.A. 2011a. Advances in Glomeromycota taxonomy and classification. IMA Fungus 2: 191-199.

Oehl F., da Silva G.A., Goto B.T., Maia L.C., Sieverding E. 2011b. Glomeromycota: two new classes and a new order. Mycotaxon 116: 365-379.

Oehl F., da Silva G.A., Goto B.T., Sieverding E. 2011c. Glomeromycota: three new genera and glomoid species recognized. Mycotaxon 116: 75-120.

Oehl F., da Silva D.K.A., Maia L.C., de Sousa N.M.F., Vieira H.E.E., da Silva G.A. 2011d. Orbispora gen. nov., ancestral in the Scutellosporaceae (Glomeromycetes). Mycotaxon 116: 161-169.

Oehl F., da Silva G.A., Sánchez-Castro I., Goto B.T., Maia L.C., Vieira H.E.E., Barea J-M., Sieverding E., Palenzuela J. 2011e. Revision of Glomeromycetes with entophosporioid and glomoid spore formation with three new genera. Mycotaxon 117: 297-316.

Omar M.B., Bollan L., Heather W.A. 1979. A permanent mounting medium for fungi. Bull. Br. Mycol. Soc. $13:$ 31-32.

Palenzuela J., Ferrol N., Boller T., Azcón-Aquila C., Oehl F. 2008. Otospora bareai, a new fungal species in the Glomeromycetes from a dolomitic shrub-land in the natural park of Sierra de Baza (Granada, Spain). Mycologia 100: 296-305.

Paulitz T.C., Menge J.A. 1986. The effects of a mycoparasite on the mycorrhizal fungus, Glomus desertiola. Phytopathol. 76: 351-354.

Pongrac P., Sonjak S., Vogel-Mikuš K., Kump P., Nečemer M., Regvar M. 2009. Roots of metal hyperaccumulating population of Thlaspi praecox (Brassicaceae) harbour arbuscular mycorrhizal and other fungi under experimental conditions. Int. J. Phytorem. 11: 347-359.

Ragupathy S., Mahadevan A. 1993. Distribution of vesicular-arbuscular mycorrhizae in the plants and rhizosphere soils of the tropical plains, Tamil Nadu, India. Mycorrhiza 3: 123-136.

Ronquist F., Huelsenbeck J.P. 2003. MRBAYES 3: Bayesian phylogenetic inference under mixed models. Bioinformatics 19: 1572-1574.

Schenck N.C., Smith G.S. 1982. Additional new and unreported species of mycorrhizal fungi (Endogonaceae) from Florida. Mycologia 74: 77-92.

Schönbeck F. 1978. Einfluss der endotrophen Mykorrhiza auf die Krankheitsresistenz höherer Pflanzen. Z PflKrankh PflSchutz 85: 191-196.

Schüßler A., Krüger M., Walker C. 2011. Revealing natural relationships among arbuscular mycorrhizal fungi: culture line BEG47 represents Diversispora epigaea, not Glomus versiforme. PLoS ONE 6(8), e23333. DOI:10.1371/journal.pone.0023333

Schüßler A., Walker C. 2010. The Glomeromycota. A species list with new families and new genera. Schüßler A., Walker C. Gloucester, Published in libraries at Royal Botanic Garden Edinburgh, Kew, Botanische Staatssammlung Munich, and Oregon State University: 56. 
Schwarzott D., Walker C., Schüßler A. 2001. Glomus, the largest genus of the arbuscular mycorrhizal fungi (Glomales) is nonmonophyletic. Mol. Phyl. Evol. 21: 190-197.

da Silva G.A., Lumini E., Maia L. C., Bonfante P., Bianciotto V. 2006. Phylogenetic analysis of Glomeromycota by partial LSU rDNA sequences. Mycorrhiza 16: 183-189.

Smith S.E., Read D.J. 2008. Mycorrhizal symbiosis. 3rd ed. San Diego: Academic Press. 787 pp.

Stutz J.C., Morton J.B. 1996. Successive pot cultures reveal high species richness of arbuscular mycorrhizal fungi in arid ecosystems. Can. J. Bot. 74: 1883-1889.

Stürmer S.L., Morton J.B. 1997. Developmental patterns defining morphological characters in spores of four species in Glomus. Mycologia 89: 72-81.

Sylvia D.M. 1986. Spatial and temporal distribution of vesicular-arbuscular mycorrhizal fungi associated with Uniola paniculata in Florida foredunes. Mycologia 78: 728-734.

Sylvia D.M., Will M. E. 1988. Establishment of vesicular-arbuscular mycorrhizal fungi and other microorganisms on a beach replenishment site in Florida. Appl. Environm. Microbiol. 54: 348-352.

Sýkorová Z., Börster B., Zvolenská S., Fehrer J., Gryndler M., Vosátka M., Redecker D. 2012. Long-term tracing of Rhizophagus irregularis isolate BEG140 inoculated on Phalaris arundinaceae in a coal mine spoil bank, using mitochondrial large subunit rDNA markers. Mycorrhiza 1: 69-80.

Tadych M., Błaszkowski J. 2000. Arbuscular fungi and mycorrhizae (Glomales) of the Słowiński National Park, Poland. Mycotaxon 74: 463-483.

Tamura K., Peterson D., Peterson N., Stecher G., Nei M., Kumar S. 2011. MEGA5: Molecular Evolutionary Genetics Analysis using Maximum Likelihood, Evolutionary Distance, and Maximum Parsimony Methods. Molecular Biology and Evolution 28: 2731-2739.

Thompson J.D., Higgins D.G., Gibson T.J. 1994. Clustal W: improving the sensitivity of progressive multiple sequence alignment through sequence weighting, position-specific gap penalties and weight matrix choice. Nucleic Acids Res. 22: 4673-4680.

van Tuinen D., Zhao B., Gianinazzi-Pearson V. 1988. PCR in studies of AM fungi: from primers to application. (In:) A.K. Varma (ed.). Mycorrhizal manual: 387-399. Springer, Berlin Heidelberg New York.

Trappe J.W., Bloss E., Menge J. 1984. Glomus deserticola sp. nov. Mycotaxon 20: 123-127.

Walker C. 1983. Taxonomic concepts in the Endogonaceae: spore wall characteristics in species descriptions. Mycotaxon 18: 443-455.

Walker C. 1985. Taxonomy of the Endogonaceae. (In:) R. Molina (ed.). 6th North American Conference on Mycorrhizae. Proceedings, pp. 193-198. Forest Research Laboratory, Corvallis, Oregon.

Walker C., Koske R.E. 1987. Taxonomic concepts in the Endogonaceae: IV. Glomus fasciculatum redescribed. Mycotaxon 30: 253-262.

Walker C., Vestberg M. 1994. A simple and inexpensive method for producing and maintaining closed pot cultures of arbuscular mycorrhizal fungi. Agr. Sci. Finland 3: 233-240.

White T.J., Bruns T., Lee S., Taylor J. 1990. Amplification and direct sequencing of fungal ribosomal RNA genes for phylogenetics. (In:) M. A. Innis et al. (eds). PCR protocols: a guide to methods and amplifications: 315-322. Academic Press, San Diego, California.

\section{Uzupełnione diagnozy dwóch taksonów - Septoglomus deserticola \\ i Diversisporaceae oraz nowe kombinacje w obrębie rodzajów \\ Glomus i Corymbiglomus}

\section{Streszczenie}

Przedstawiono uzupełnioną definicję morfologii zarodników Septoglomus deserticola, arbuskularnego grzyba mikoryzowego z gromady Glomeromycota, na podstawie oryginalnego opisu tego gatunku, jego jedynej innej definicji opublikowanej niedawno i zarodników wyhodowanych w kulturach wazonowych zainokulowanych glebą ryzosfrową i fragmentami korzeni nierozpoznanej trawy kolonizującej piaszczyste wydmy nadmorskie Półwyspu Hicacos, Kuba. 
Analizy filogenetyczne sekwencji dużej podjednostki (LSU) jądrowego rDNA kubańskiego grzyba potwierdzily jego powinowactwo z $S$. deserticola zdeponowanym w Międzynarodowym Banku Glomeromycota (BEG) i wykazały, że jego najbliższymi krewniakami są $S$. fuscum i $S$. xanthium. Analizy filogenetyczne sekwencji małej podjednostki (SSU) jądrowego rDNA potwierdziły pokrewieństwo trzech taksonów: grzyb kubański x $S$. fuscum $\mathrm{x} S$. xanthium ujawnione w analizach sekwencji LSU i przez to zasugerowały, że kubańskie $S$. deserticola jest właściwym S. deserticola. Jednak nie było możliwości dowieść bezpośrednio identyczności kubańskiego $S$. deserticola z typowym $S$. deserticola z BEG na podstawie sekwencji SSU z powodu braku sekwencji SSU $S$. deserticola w dostępnych bazach danych. Ponadto analizy filogenetyczne sekwencji LSU i SSU potwierdziły unikatowość niedawno utworzonego rodzaju Corymbiglomus z gatunkiem typowym C. corymbiforme (wcześniejszym Glomus corymbiforme) w rodzinie Diversisporaceae i dowiodły, że jego sekwencje LSU grupują się w kladzie z sekwencjami LSU Glomus globiferum i G. tortuosum. W konsekwencji dwa ostatnie gatunki zostały przeniesione do rodzaju Corymbiglomus i nazwane $C$. globiferum comb. nov. oraz C. tortuosum comb. nov., a definicje rodziny Diversisporaceae i rodzaju Diversispora zostały uzupełnione. 